Nig. J. Biotech. Vol. 38 (1) : 40-47 (June 2021)

ISSN: 01891731

Available online at

http://www.ajol.info/index.php/njb/index

and www.biotechsocietynigeria.org

DOI: https://dx.doi.org/10.4314/njb.v38i1.4

\title{
Assessment of Genetic Diversity in Bambara Groundnut (Vigna subterranea) Landraces Based on Seed Storage Proteins Electrophoretic Pattern
}

\author{
N. M. Saminu., B.G. Kurfi. and Y. Y. Muhammad* \\ Department of Biochemistry, Bayero University, Kano, Nigeria.
}

\begin{abstract}
Bambara groundnut (Vigna subterranea) is a leguminous crop that is considered underutilized and has previously received little research attention. Variability in a number of physiological factors, including germination rate, widely affects its production. Seed storage protein, its fractions and protein profile of six Bambara groundnut local landraces were studied to assess their genetic relatedness. Total seed storage protein and its fractions were estimated by Bradford's method. SDS-PAGE analysis was used to evaluate storage protein profile. The results showed significant differences $(p<0.05)$ in protein contents among the landraces. The major seed storage proteins were found to be globulins $(0.048$ to $0.088 \mathrm{mg} / \mathrm{mL} \quad$ ), albumins $(0.023$ to $0.038 \mathrm{mg} / \mathrm{mL} \quad)$, glutelins $(0.007$ to $0.013 \mathrm{mg} / \mathrm{mL} \quad)$ and prolamins $(0.002$ to $0.004 \mathrm{mg} / \mathrm{mL} \quad$ ). Five peptide bands were detected with molecular weights corresponding to $97.4 \mathrm{kDa}, 45 \mathrm{kDa}, 29 \mathrm{kDa}, 20.1 \mathrm{kDa}$ and $18 \mathrm{kDa}$, respectively. Three peptide bands corresponding to $97.4 \mathrm{kDa}, 45 \mathrm{kDa}$ and $18 \mathrm{kDa}$ were detected in all the landraces and two peptide bands between $29 \mathrm{kDa}$ and $20.1 \mathrm{kDa}$ were detected in five landraces. Dendrogram generated by UPGMA grouped the six landraces into one major cluster with two sub-clusters. The observed diversity in storage protein pattern of the landraces indicated their potential as materials for crop improvement.
\end{abstract}

Keywords: Bambara groundnut; landraces; storage protein; SDS-PAGE; genetic diversity.

*Author for correspondence: yymuhammad.bch@buk.edu.ng

\section{Introduction}

Bambara groundnut (Vigna subterranea (L.) Verdc.) is a leguminous crop that is native to Africa ; it is commonly cultivated for its seeds by subsistence farmers (Linnemann and Azam-Ali, 1993; Massawe et al., 2005) and has the prospect of contributing to climate change ready agriculture (Mayes et al., 2019). Among the legumes in Africa, Bambara groundnut has been reported to be the most important after groundnut and cowpea with which it shares its origin of genetic diversity. Though extensively grown in Nigeria, it has been reported to be one of the crops less investigated scientifically (Bamshaiye et al., 2011). Genetic diversity is of great importance in implementing successful breeding programs in both vegetatively and sexually propagated crops, the variation can occur naturally or artificially (Agbolade et al., 2016). One of the techniques employed for assessing the genetic variability and relatedness among crop germplasms is the analysis of seed storage protein profile, and it stands as an alternative and a valid method for varietal or species identification (Menella et al., 1999; Naworu, 2020). Proteins are dynamic in nature, hence the differences in their characteristics defines one from another. Studies on storage protein, its fractions and peptide pattern of some Bambara groundnut landraces indicated differences among landraces in terms of their protein content and molecular weights (Paulter, 1981; Odeigah and Osanyinpeju, 1998; Oludare et al., 2017). The biosynthesis of seed storage proteins takes place in the developing embryo 
when cell division is complete. These proteins which accumulate in protein bodies in the cotyledonary parenchyma cells are distinguished from other proteins by their lack of any functional activity besides storage and are utilized during germination and seedling establishment (Surekha and Mandal, 2000; Li et al., 2006). Seed storage proteins have varied solubility, and this serves as the basis for their classification. Albumins are water soluble, globulins are salt soluble, glutelins are alcohol soluble while the glutelins are alkali soluble (Surekha and Mandal, 2000). Seed storage proteins are genetic markers that have found utility in intra- and inter-species genetic diversity analyses, conservation of genetic resources and as a molecular tool in crop improvement (Ghafoor et al., 2002). The genetic diversity of storage proteins can be very useful for breed lines analysis and enhanced nutritional quality of crop varieties by indicating lines having variably expressed storage proteins (Shende et al., 2019). As proteins are direct products of gene expression, the electrophoretic banding of proteins from any species can be used to evaluate the genetic variability within and with other species (Agbolade et al., 2017).

\section{Materials and Methods}

\section{Sample collection and preparation}

Seeds for six landraces of Bambara groundnut were locally obtained from Niger, Yobe and Kano States of Nigeria (Figure 1). The seeds were identified in the Department of Plant Biology, Bayero University, Kano, with a voucher number '0509'. The seeds were named Niger cream, Yobe cream, Yobe black, Kano mottled, Kano maroon and Kano brown based on their places of collection and colours. Only seeds with normal shapes were used, while those displaying any visible damage or abnormal shape were discarded. The seeds were cleaned by washing with distilled water. Twenty (20) randomly selected seeds from each landrace were weigh ed and crushed using a mortar and pestle into flour, sieved and stored in airtight plastic containers.

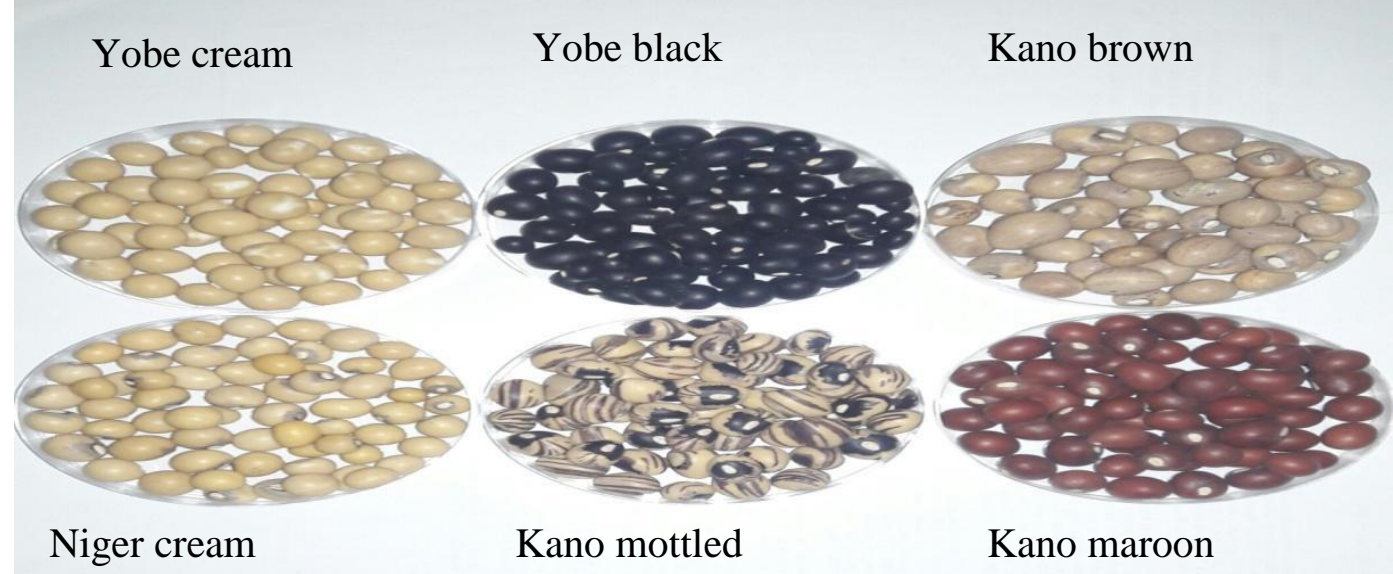

Figure 1: Bambara groundnut landraces obtained from three different states of $\mathrm{N}$ orthern Nigeria

\section{Extraction of total storage protein}

Seeds flour was transferred into a $250 \mathrm{~mL}$ beaker and defatted with $n$-hexane $(1: 3, w / v)$ at room temperature by continuous shaking for thirty minutes and then allowed to settle. The hexane was removed by decantation and the flour left to dry at room temperature. The extraction of total proteins was done according to Hameed et al. (2009). Seed flour (1 g) was dissolved in a $10 \mathrm{~mL}$ extraction buffer (50 $\mathrm{mM}$ phosphate buffer, $\mathrm{pH}$ 7.8). The homogenate was vortexed and centrifuged at $14,000 \mathrm{rpm}$ for
10 minutes at $4^{\circ} \mathrm{C}$. The supernatant was used for total protein estimation and sodium dodecyl sulphate polyacrylamide gel electrophoresis (SDS-PAGE) analysis.

\section{Extraction of storage protein fractions}

Storage protein fractions were sequentially extracted based on their solubility (Silva et al., 2016). Seeds flour $(1 \mathrm{~g})$ was dissolved in $10 \mathrm{~mL}$ distilled water, the homogenate was incubated for 30 minutes at $30{ }^{\circ} \mathrm{C}$ and subsequently centrifuged at $3000 \times \mathrm{g}$ for 20 minutes. The 
supernatant was recovered and the pellet resuspended in $5 \mathrm{~mL}$ distilled water, incubated for 30 minutes at $30{ }^{\circ} \mathrm{C}$ and centrifuged at $3000 \times \mathrm{g}$ for 20 minutes. The supernatants were combined as albumin fraction. Globulins fraction was extracted in a similar manner using $1 \% \mathrm{NaCl}$ as the solvent; glutelins fraction was extracted with $0.1 \mathrm{M} \mathrm{NaOH}$ while prolamins fraction was extracted with $70 \%$ ethanol.

\section{Estimation of protein}

Protein quantification was carried out according to Bradford's method using bovine serum albumin (BSA) as the standard (Bradford, 1976).

Determination of storage protein banding pattern SDS-PAGE analysis of total storage proteins from the six Bambara groundnut landraces was carried out in $12 \%$ polyacrylamide slab gels according to the method of Laemmli (1970). Ten microliters $(10 \mu \mathrm{l})$ each of the protein ladder (acculadder ${ }^{\mathrm{TM}}$ Protein size marker, $6.5 \mathrm{kDa}$ to $116 \mathrm{kDa}$ ) and samples were loaded into the wells of stacking gel. Electrophoresis was done at $80 \mathrm{~V}$ for 1 hour until the bromophenol blue ran to the bottom of the gel. After electrophoresis the gels were stained with $2 \%$ coomassie blue for 1 hour and destained by solution containing $5 \%(\mathrm{v} / \mathrm{v})$ acetic acid, 20\% (v/v) methanol and distilled water in the ratio of $5: 20: 75(\mathrm{v} / \mathrm{v})$ for 2 hours.

\section{Assessment of seed storage protein diversity}

The diversity of storage protein profiles was assessed using Jaccard's similarity matrix based on the presence or absence of peptide bands in the electrophoretic pattern of total seed storage proteins. Depending on the presence or absence of a band, peptide was scored 1 for presence and 0 for absence of band and the score was used to generate a similarity matrix. The similarity index was converted into a dissimilarity index using the relationship: dissimilarity $=1-$ similarity. Following an unweighted pair-group method with arithmetic averages (UPGMA), the dissimilarity values were used to generate a dendrogram.

\section{Statistical analysis}

All data are presented as the mean \pm standard deviation of three replicate analyses. For comparison, data were analyzed by one-way ANOVA. Tu key's test was used to determine the differences between protein content among Bambara groundnut landraces. All statistical analysis was based on a significant level of 0.05 . Analyses were done with SPSS Statistics version 16.0 .

\section{Results}

The concentrations of total seed storage protein and protein fractions of the Bambara groundnut landraces are presented in Table 1 . The results indicate that total seed storage protein content differed significantly $(p<0.05)$ in Yobe cream, Yobe black and Kano brown landraces. There was significant $(p<0.05)$ difference in albumin content of Yobe black landrace. Globulin content differed significantly $(p<0.05)$ in Yobe cream and Kano brown landraces. Glutelin content differed significantly $(p>0.05)$ Yobe black and Kano mottled landraces. Prolamin content shows significant $(p<0.05)$ difference in Yobe cream, Kano mottled and Kano landraces.

Table 1: Protein content of six Bambara groundnut landraces

\begin{tabular}{llllll}
\hline & \multicolumn{5}{c}{ Protein concentration $(\mathbf{m g} / \mathbf{m L})$} \\
\cline { 2 - 6 } Landraces & Total protein & Albumins & Globulins & Glutelins & Prolamins \\
\hline Niger cream & $0.090^{\mathrm{a}} \pm 0.003$ & $0.023^{\mathrm{a}} \pm 0.002$ & $0.058^{\mathrm{a}} \pm 0.003$ & $0.007^{\mathrm{a}} \pm 0.001$ & $0.002^{\mathrm{a}} \pm 0.001$ \\
Yobe cream & $0.111^{\mathrm{b}} \pm 0.001$ & $0.027^{\mathrm{a}} \pm 0.006$ & $0.069^{\mathrm{b}} \pm 0.002$ & $0.008^{\mathrm{a}} \pm 0.002$ & $0.004^{\mathrm{b}} \pm 0.001$ \\
Yobe black & $0.102^{\mathrm{c}} \pm 0.001$ & $0.038^{\mathrm{b}} \pm 0.002$ & $0.059^{\mathrm{a}} \pm 0.003$ & $0.013^{\mathrm{b}} \pm 0.002$ & $0.002^{\mathrm{a}} \pm 0.001$ \\
Kano mottled & $0.088^{\mathrm{a}} \pm 0.002$ & $0.024^{\mathrm{a}} \pm 0.005$ & $0.050^{\mathrm{c}} \pm 0.002$ & $0.010^{\mathrm{b}} \pm 0.001$ & $0.004^{\mathrm{b}} \pm 0.001$ \\
Kano maroon & $0.085^{\mathrm{a}} \pm 0.000$ & $0.028^{\mathrm{a}} \pm 0.000$ & $0.048^{\mathrm{c}} \pm 0.001$ & $0.007^{\mathrm{a}} \pm 0.002$ & $0.002^{\mathrm{a}} \pm 0.001$ \\
Kano brown & $0.125^{\mathrm{d}} \pm 0.003$ & $0.025^{\mathrm{a}} \pm 0.002$ & $0.088^{\mathrm{d}} \pm 0.004$ & $0.008^{\mathrm{a}} \pm 0.000$ & $0.003^{\mathrm{c}} \pm 0.000$ \\
\hline
\end{tabular}

Data are expressed as mean \pm standard deviation of triplicate measurements. Means with different superscripts across columns are significantly different $(p<0.05)$. 
SDS-PAGE analysis of the total seed storage protein (Figure 2) revealed similarities in peptide pattern between the studied Bambara groundnut landraces even though there were some observable differences in terms of number of peptide bands detected. Niger cream and Yobe cream landraces have the highest number of bands with five bands each, followed by Yobe black, Kano maroon and Kano brown with four bands each and then Kano mottled with 3 bands. All the six landraces have 3 bands in common, corresponding to $97.4 \mathrm{kDa}, 45 \mathrm{kDa}$ and $18 \mathrm{kDa}$. Two bands between $20.1 \mathrm{kDa}$ and $29 \mathrm{kDa}$ were detected except in the Kano mottled landrace.

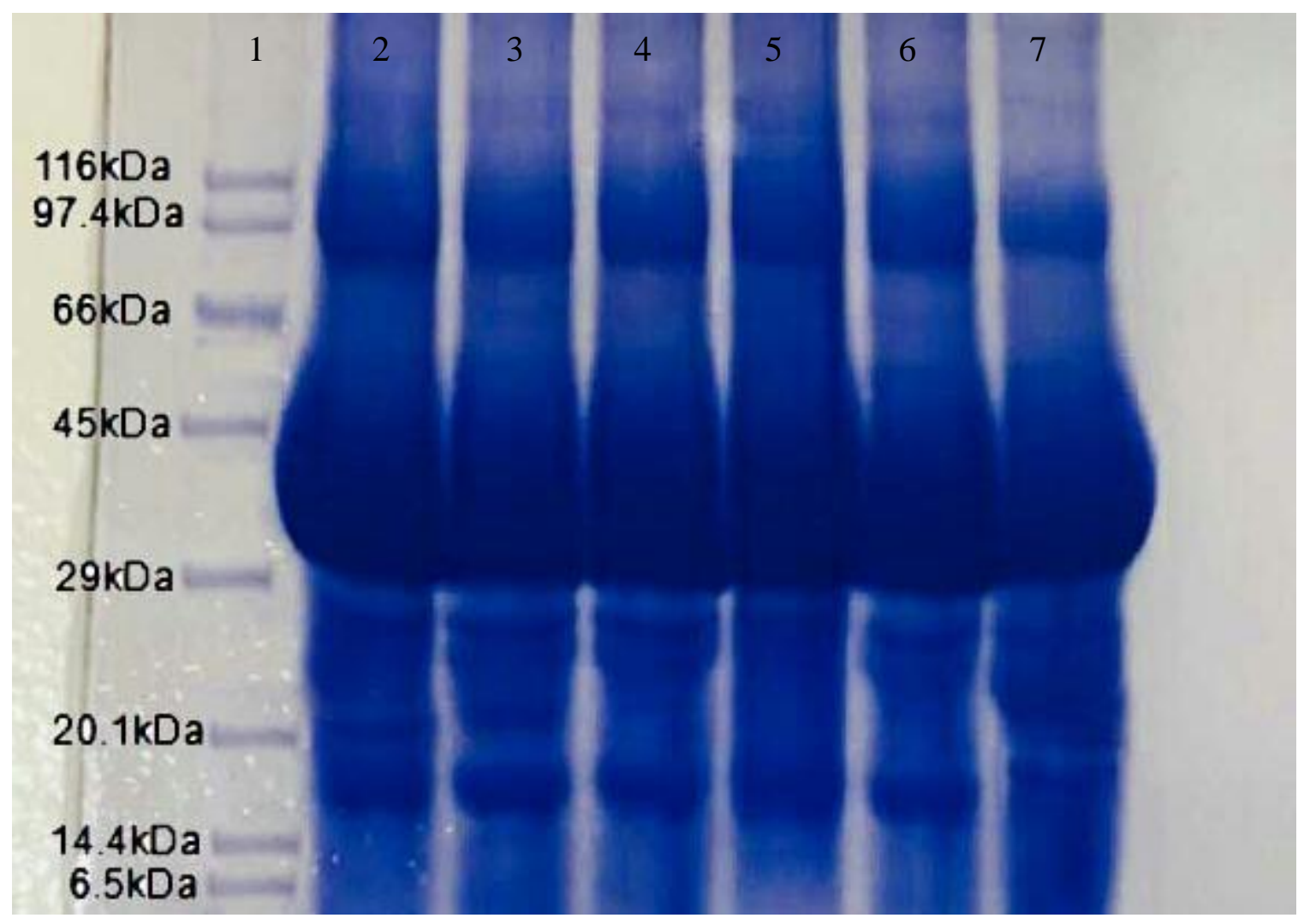

Figure 2: Seed protein peptides pattern of the six Bambara groundnut landraces.

Lane $1=$ molecular weight marker, lane 2 = Niger cream landrace, lane $3=$ Yobe cream landrace, lane 4 $=$ Yobe black landrace, lane $5=$ Kano mottled landrace, lane $6=$ Kano maroon landrace and lane $7=$ Kano brown landrace.

Hierarchical cluster analysis put the six landraces into one cluster $(A)$, having two sub-clusters $A 1$ and A2 (Figure 3). Sub-cluster A1 consisted of Yobe black, Kano maroon and Kano mottled landraces, while sub-cluster A2 consisted of Niger cream, Yobe cream and Kano brown landraces. 
Rescale Distance Cluster Combine

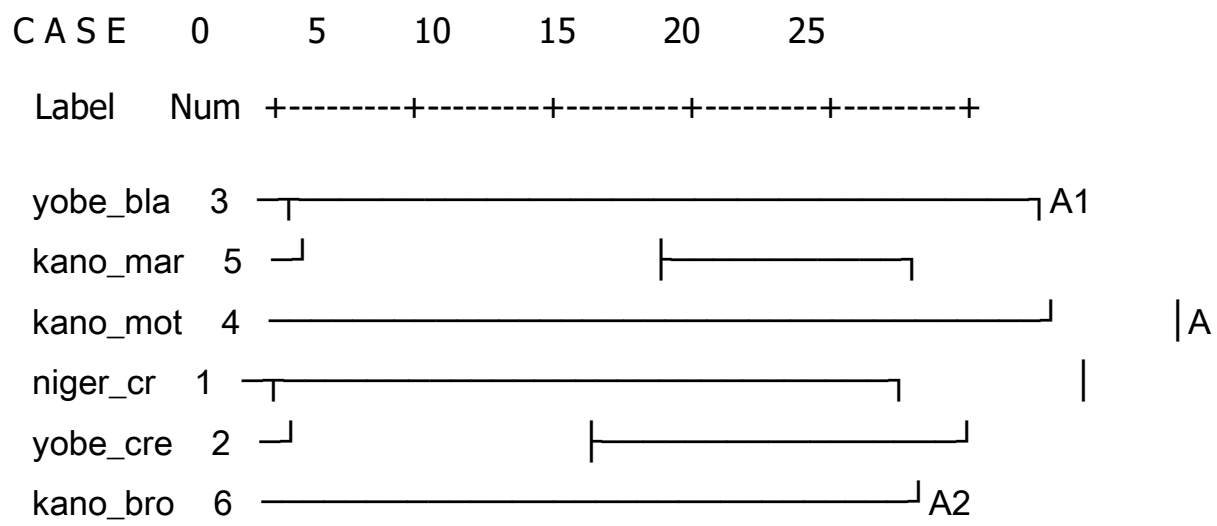

Figure 3: Dendrogram of protein profile for six Bambara groundnut landraces generated by Unweighted Pair-Group Method with Arithmetic averages (UPGMA) method using SPSS Version 16.0 Statistical Software. niger_cr $=$ Niger cream, yobe_cre $=$ Yobe cream, yobe_bla $=$ Yobe black, kano_mot $=$ Kano mottled, kano_mar $=$ Kano maroon and kano_bro $=$ Kano brown landraces.

Table 2 shows the closeness between any two landraces based on Jaccard's similarity matrix. Niger cream - Yobe cream and Yobe black - Kano maroon have a similarity index of 1 which is the highest among the studied landraces. Kano mottled - Kano brown landraces had the lowest similarity index of 0.40 .

Table 2: Similarity Index of six Bambara groundnut landraces based on their peptides profile

\begin{tabular}{|c|c|c|c|c|c|c|}
\hline \multicolumn{7}{|l|}{ Similarity index } \\
\hline Landrace & Niger cream & $\begin{array}{l}\text { Yobe } \\
\text { cream }\end{array}$ & $\begin{array}{l}\text { Yobe } \\
\text { black }\end{array}$ & $\begin{array}{l}\text { Kano } \\
\text { mottled }\end{array}$ & $\begin{array}{l}\text { Kano } \\
\text { maroon }\end{array}$ & Kano brown \\
\hline Niger cream & 1.00 & & & & & \\
\hline Yobe cream & 1.00 & 1.00 & & & & \\
\hline Yobe black & 0.80 & 0.80 & 1.00 & & & \\
\hline Kano mottled & 0.60 & 0.60 & 0.75 & 1.00 & & \\
\hline Kano maroon & 0.80 & 0.80 & 1.00 & 0.75 & 1.00 & \\
\hline Kano brown & 0.80 & 0.80 & 0.60 & 0.40 & 0.60 & 1.00 \\
\hline
\end{tabular}

Similarity index generated by pairing and comparing each of the landraces with one another.

\section{Discussion}

Seeds of plants contain one or more groups of proteins that supply amino acids important during germination and seedling establishment. These storage proteins are important because they determine both the quantity and quality of seed proteins for various metabolic uses (Alwhibi, 2017). In the present study, total seed storage proteins and its four fractions differed significantly among the Bambara groundnut landraces. Odeigah and Osanyinpeju (1998) and Oludare et al., (2017) reported seed storage protein content of Bambara groundnuts within the same range (0.053 to $0.066 \mathrm{mg} / \mathrm{ml})$. However, Poulter (1981) reported albumin fractions having the highest content (20.34 to $74.46 \%$ ) in Bambara groundnut cultivars, followed by globulin fractions (2.52 to $46.30 \%$ ) while Yagoub and Abdalla (2007) reported albumin fractions $(72.64 \%)$ as the major storage protein, followed by glutelin $(8.60 \%)$, globulin (8.20) and then prolamin fractions $(0.84 \%)$. The differences in protein content can be a reflection of genetic variation existing in the crop since proteins are the primary products of gene expression. Also nutritionally, the Bambara groundnut seed contains all the four types of 
storage proteins making it an idle crop that can be used to supplement protein in cereal crops diet.

SDS-PAGE analysis of the seed storage protein shows that the Bambara groundnut landraces studied have similarity in electrophoretic band patterns irrespective of their seed colour, but slightly differ in terms of number of bands and band intensity. Niger cream (NC) and Yobe cream (YC) each have five bands $97.4 \mathrm{kDa}, 45 \mathrm{kDa}, 29$ $\mathrm{kDa}, 20.1 \mathrm{kDa}$ and $18 \mathrm{kDa}$, while each of Yobe black (YB), Kano maroon (KM) and Kano brown (KB) have four bands $97.4 \mathrm{kDa}, 45 \mathrm{kDa}, 29 \mathrm{kDa}$ and $18 \mathrm{kDa}$, Kano mottle (KC) have only 3 bands $97.4 \mathrm{kDa}, 45 \mathrm{kDa}$ and $18 \mathrm{kDa}$. A total of five (5) peptide bands with molecular weights corresponding to $97.4 \mathrm{kDa}, 45 \mathrm{kDa}, 29 \mathrm{kDa}, 20.1$ $\mathrm{kDa}$ and $18 \mathrm{kDa}$ were observed among the different landraces. These peptides correspond to phosphorylase b, oval albumin, carbonic anhydrase, trypsin inhibitor and lysozyme (Oludare et al., 2017). Odeigah and Osanyinpeju (1998) reported that SDS-PAGE of Bambara groundnut storage protein did not show any definite correlation between any polypeptide and seed phenotypic characteristics. Smartt (1990) and Odeigah and Osanyinpeju (1998) suggested that differences may be present between Bambara groundnut storage proteins at finer level which SDS-PAGE could not detect. Similar results on storage protein electrophoresis showing some slight variations in seed storage protein electrophoregrams were reported in Bambara groundnut (Odeigah and Osanyinpeju, 1998; Oludare et al., 2017), sesame (Alege, 2015) and groundnut (Muniappan et al., 2016). Dudwadkar et al. (2015) reported that the diversity and variation in seed storage proteins have potential for species delimitation and can also serve as markers for intra- and inter-specific hybridization. Landraces are an important source of genetic divergence and the greater the level of variation, the greater the chances of a landrace possessing gene combinations of interest in plant breeding (Sadia et al., 2009). There is a lack of unique bands peculiar to a specific landrace. Despite morphological diversity possessed by landraces, it seems there exist genotype duplicates among Bambara groundnut as revealed by the similar peptides pattern of some landraces. These similarities may represent the characters shared by the landraces (Odeigah and Osanyinpeju,
1998). The presence of bands of similar molecular weight across varieties signifies, among others, that the genes encoding the proteins are ubiquitous in the species (Akinwusi and Illoh, 1995). Inability of accessions or cultivars to express a peculiar band is an indication of common gene expression among the crop genotypes while possession of common bands in all studied accessions or cultivars strongly indicates that the gene coding for the peptide bands is fixed (Alege, 2015).

Cluster analysis put the six Bambara groundnut landraces into one major cluster (A) with two subclusters A1 (consisting of four landraces) and A2 (consisting of two landraces). The grouping of all six landraces into one single cluster reveals low genetic diversity among the studied landraces. The occurrence of low genetic diversity could be attributed to genotype homogeneity or purity (Peddakasim et al., 2015). Since Bambara groundnut seeds samples used in the present study were sourced from markets, the clustering pattern cannot be solely based on the environment where the seeds samples were purchased since seeds samples can be brought to market from different locations across the country. Tabatabei et al. (2011) reported that human factors are very important for the association between accessions from different locations. Results within close range of similarity coefficient were similarly reported in many other species; for example, 0.82-0.24 in cowpea cultivars and $0.96-0.47$ in sesame accessions (Osanyinpeju and Odeigah, 1998; Alege, 2015).

\section{Conclusion}

The findings from the present study indicated some variation in seed storage protein content and profile of the Bambara groundnut landraces. The observed variations indicate substantial genetic variability in storage proteins among the studied Bambara groundnut landraces indicating their potentials as materials for crop breeding and improvement. Furthermore the presence or absence of peptide bands can be useful for identification of landrace among others.

\section{References}

Agbolade, J. O. and Komolafe R. J. (2016). Genetic diversity and Phylogenetic behavior of some minor legumes. Int. J. Plant Biol., 7(1): 1521. 
Agbolade, J. O., Adekoya, M. A., David, O. A., Chukwuma, D. M., Komolafe, R. J. and Olaiya, A. E. (2017). Genetic diversity in pigeon pea (Cajanuscajan L.) Millspaugh Germplasm Revealed by Gel Electrophoresis of the Seeds' Proteins. J. Plant Sci., 5(2):48-55.

Akinwusi, O. and Illoh, H. C. (1995). Crude protein electrophoresis seeds of some species of Hibiscus. Nig. J. Bot., 8: 71-76.

Alege, G. O. (2015). Protein profile study of some Nigerian seasame (Sesamum indicum L.) accessions. Int. J. Appl. Sci. Biotech., 3(2): 322329.

Alwhibi, M. S. (2017). Characterization of seed storage protein patterns of Heliotropium digynum. Saudi J. Biol. Sci., 24(6): 1404-1409.

Bamshaiye, O. M., Adegbola, J. A. and Bamishaiye, E. I. (2011). Bambara groundnut: An under-utilized nut in Africa. Adv. Agric. Biotech., 1(1): 60-72.

Bradford, M. M. (1976). A rapid and sensitive method for the quantitation of microgram quantities of protein utilizing the principle of protein-dye binding. Anal. Biochem., 72 (1): 248254.

Dudwadkar, S., Parab, M. and Singh, S. (2015). Diversity analysis among few Cucurbataceae using seed protein profile. Int. J. Plant Animal Environ. Sci., 5(1): 146-151.

Ghafoor, A., Ahmad, Z., Qureshi, A. S. and Bashir, M. (2002). Genetic relationship in Vigna mungo (L.) hepper and Vigna radiata (L.) R. wilczek based on morphological traits and SDS-PAGE. Euphytica, 123(3): 367-378.

Hameed, A., Shah, T. M., Atta, B. M., Iqbal, N., Haq, M. A. and Ali, H. (2009). Comparative seed storage protein profiling of kabuli genotypes. Pak. J. Bot., 41(2): 703-710.

Laemmli, U. K. (1970). Cleavage of structural proteins during assembly of the head of bacteriophage T4. Nature, 227(5259): 680-685.

Li, Q., Wang, B. C., Xu, Y. and Zhu, Y. X. (2006). Systematic studies of $12 \mathrm{~S}$ seed storage protein accumulation and degradation patterns during Arabidopsis seed maturation and early seedling germination stages. J. Biochem. Mol. Biol., 40(3): 373-381.

Linnemann, A. R. and Azam-Ali, S. N. (1993). Bambara groundnut (Vigna subterranea (L.) Verdc.). In: Underutilised Crop Series $I$. Vegetables and Pulses. Chapman and Hall, London, UK.

Massawe, F. J., Mwale, S. S., Azam-Ali, S. N. and Roberts, J. A. (2005). Breeding in bambara groundnut (Vigna subterranea (L.) Verdc.): Strategic consideration. Afr. J. Biotech., 4(6): 463-471.

Mayes, S., Ho, W. K. and Chai, H. H. (2019). Bambara groundnut: an exemplar underutilised legume for resilience under climate change. Planta 250(3): 803-820.

Mennella G., Onofaro S. V., Tonini A. and Magnifico V. (1999). Seed storage protein Characterization of Solanum specied cultivars and androgenic lines of $S$. melongena L., by SDSPAGE and AE-HPLC. Seed Sci. Technol., 27(1): 23-35.

Muniappan, V., Palanivel, S., Parvathi, S., Viswanathan, M. B. and Rajesh, R. (2016). Analysis of seed proteins in groundnut cultivers (Arachis hypogaea). Int. J. Eng. Res. Applic., 6(7): 6-10.

Naworu J. (2020). Studies on Bambara groundnut (Vigna subterranea (L.) Verdc.) induced with sodium azide using sodium dodecyl sulphate polyacrylamide gel electrophoresis. University of Ibadan Faculty of Science. https://authorea.com/users/361769/articles/483 110-studies-on-bambara-groundnut-vignasubterranea--verdc-induced-with-sodium-azideusing-sodium-dodecyl-sulphate-polyacrylamidegel-electrophoresis-sds-page

Odeigah, P. G. C. and Osanyinpeju, A. O. (1998). Evaluating the genetic biodiversity of bambara groundnut accessions from Nigeria using SDSpolyacrylamide gel electrophoresis. Gen. Res. Crop Evol., 45 (5): 451-458.

Oludare, A. J., Kioko, J. I., Akeem, A. A., Olumide, 
A. T., Justina, K. F., Adejoke, I. M., Oyenade, D. A., Moradeke, C. D. and Aderonka, O. (2017). Genetic diversity in bambara groundnut (Vigna subterranea (L.) Verdc.) as revealed by molecular weights of the seeds' proteins. Bangladesh J. Plant Breed. Genet., 30(2): 19-28.

Osanyinpeju, A. O. and Odeigah, P. G. C. (1998). Variation in seed proteins from mutagen-treated cultivars and selected lines of Vigna unguiculata L. Walp. Plant Breed., 117(4): 361-365.

Peddakasim, D., Suneetha, P., Lakshmi, S. U., Srideepthi, R. and Krishna, M. S. R. (2015). Seed storage protein profiling and phylogenetic relationships of Capsicum annun L. cultivars using SDS-PAGE. Res. J. Biotech., 10(2): 1-4.

Poulter, N. H. (1981). Properties of some protein fractions from bambara groundnut (Voandzeia subterranea). J. Sci. Food Agric., 32(1): 44-50.

Sadia, M., Malik, S. A., Rabbani, M. A. and Pearce, S. R. (2009). Electrophoretic characterization and relationships between some Brassica species. Electron. J. Biol., 5(1): 1-4.

Shende R. T., Sheilendra P. and Kanchan S. B. (2019). Seed protein profiling of rice genotypes. J. Pharmacog. Phytochem., 8(3): 4131-4137.

Silva, S., Francisco, F. and Dantas, F. (2016). Quantification of storage proteins during seed imbibitions of native species from the brazillian catinga vegetation. Ciencias Agrarias, 37(4): 1733-1143.

Smart, J. (1990). The Old World Pulses: Vigna species. In: Grain Legumes: Evolution and Genetic Resources, 140-175. Cambridge University Press, Cambridge.

Surekha, Mandal and Mandal, R. K. (2000). Seed storage proteins and approaches for improvement of their nutritional quality by genetic engineering. Current Science, 79(5): 576589.

Tabatabaei, I., Pazouki, L., Bihamta, R. M., Mansoori, S., Javaran, M. J. and Niinemets, U. (2011). Genetic variation among Iranian sesame (Sesamum indicum L.) accessions vis-à-vis exotic genotypes on the basis of Morpho-physiolocal traits and RAPD markers. Australian J. Crop Sci., 5(11): 1396-1407.

Yagoub, A. E. A. and Abdalla, A. A. (2007). Effect of domestic processing methods on chemical compositon, in vitro digestibility of protein and starch, and functional properties of bambara groundnut (Voandzeia subterranea) seed. Res. J. Agric. Biol. Sci., 3(1): 24-34. 